\title{
The use of brick-lime plasters and their relevance to climatic conditions of historic bath buildings
}

\author{
Elif Uğurlu, Hasan Böke* \\ Architectural Restoration Department, İzmir Institute of Technology, 35430 İzmir, Turkey
}

\section{A R T I C L E I N F O}

\section{Article history:}

Received 5 December 2007

Received in revised form 14 October 2008

Accepted 23 October 2008

Available online 5 December 2008

\section{Keywords}

Brick

Lime

Plaster

Climate

Durability

Ottoman bath

\begin{abstract}
A B S T R A C T
Brick-lime mortars and plasters have been widely used as water-proof materials in aqueducts, bridges and cisterns since early Hellenistic time. In this study, the characteristics of brick-lime plasters used in some Ottoman bath buildings were investigated in order to understand their relevance as plasters in hot and humid environmental conditions of the baths. For this purpose, basic physical properties, raw material compositions, mineralogical, microstructural and hydraulic properties of brick-lime plasters of some historic bath buildings in Izmir (Turkey) were determined by XRD, SEM-EDX, AFM and chemical analyses. The results indicated that their survival without loosing their strength and adhesion in hot and humid conditions of the baths was explained by their hydraulic characters due to the consciously use of porous and pozzolanic crushed bricks as aggregate in the manufacturing of plasters.
\end{abstract}

(c) 2008 Elsevier Ltd. All rights reserved.

\section{Introduction}

Brick-lime mortars and plasters known as Cocciopesto in Roman times are produced by mixing crushed bricks with lime [1]. They have hardened by both the carbonation of lime and the reaction between lime and amorphous silicates and aluminates in the composition of the bricks in the presence of water. Amorphous materials react with lime to produce calcium silicate hydrates and calcium aluminate hydrates that give high strength to the mortars and plasters and cause the plaster and mortar to set under water [2]. Due to their setting under water, brick-lime mortars and plasters have been mostly used as masonry mortars and finishing materials in the construction of aqueducts, bridges, cisterns and bath buildings. They were also used as paving layer on floors and terraces and as a supporting material for mosaics [1].

The importance of the use of brick-lime mortars and plasters in the humid or wet spaces of the buildings has been known since Roman period. Vitruvius stated that crushed bricks should be used in the first plaster layers of the walls subjected to high humidity [3]. On the other hand he suggested the use of natural pozzolans instead of brick powders in the mortars of the walls.

Characteristics of brick-lime mortars and plasters were mentioned and discussed throughout eighteenth and nineteenth centuries in England and France [4]. In 1744, Loriot asserted that mortars which were prepared with lime and heated clay minerals instead

\footnotetext{
* Corresponding author. Tel.: +90 232 7507035; fax: +90 2327507012

E-mail address: hasanboke@iyte.edu.tr (H. Böke).
}

of lime and brick dust set much quicker, and they would be perfect water-proof materials for the lining of cisterns, etc [4]. He defined that the mortars composed of one part of finely sifted brick dust, two parts of fine river sand, and slaked lime as old as possible and powdered quicklime as one fourth of the whole amounts of aggregates should be well mixed and used as soon as possible. Otherwise, their application would be imperfect or impossible. However, Higgins and Rondelet quoted but disapproved the method of Loriot. They pointed out that mortar set very quickly by the addition of powdered quicklime but it lost its superiority after a certain period of time due to high amount of lime while common mortars acquired consistency and hardness equal to hard stones in this period [4].

In 1824, White stated that artificial pozzolans produced by heating clay minerals up to vitrification temperatures were not appropriate materials to obtain good mortar. He defined that brick aggregates and lime must be used in the lime/aggregate ratios between $1: 3$ and $1: 4$ and to provide a good adhesion, they should be finely powdered [4].

In 1828 , Vicat described three heating methods of clay minerals to produce artificial pozzolans. In the first method; clay minerals were heated on an iron plate that was brought to glow for 20 $25 \mathrm{~min}$ and stirring the powder constantly in the mean time. In the second method; powdered clay minerals were mixed with combustible substances such as saw-dust and chopped straw in order to obtain a porous structure. When the mixture was dry enough it was burned in the upper part of a lime kiln where the heat was moderate. In the third method, clay minerals were 
crushed into small pieces less than a man's fist and then they were heated at moderate temperature in an open air-kiln [5].

Vicat mentioned that all clay minerals would be very energetic artificial pozzolans if they were heated by the two first methods [5]. They would be only energetic pozzolans if burned by the third method, and a little energetic pozzolans if burned to the hardness of strong bricks. According to him, weakly hydraulic lime must be mixed with energetic pozzolans and highly hydraulic lime may be combined with little energetic pozzolans in order to obtain good hydraulic mortars.

The characteristics of the bricks used in the manufacturing of lime mortars and plasters were defined in the specification of building materials in Ottoman period. In the specifications, the well-fired and newly produced bricks were suggested in the manufacturing of mortars and plasters [6].

In recent studies, raw material compositions, mineralogical, microstructural and hydraulic properties of brick-lime mortars and plasters of different historic buildings were determined in order to understand their manufacturing technology and to produce compatible repair mortars and plasters with the existing ones [7$12]$. The investigated mortars and plasters presented different binder/aggregate ratios varying from $1: 4$ to $1: 2$. Binders were mostly composed of calcite due to carbonated lime and calcium silicate hydrates and calcium aluminate hydrates that are formed as a result of the reaction between lime and brick aggregates.

In a few recent studies, the characteristics of the bricks that were used as aggregates in the production of mortars and plasters have been defined. These studies indicated that bricks must be prepared with a high amount of clay minerals and must be fired at low temperatures $\left(600-900^{\circ} \mathrm{C}\right)$ to have good pozzolanicity $[13,14]$.

In this study, the characteristics of brick-lime plasters collected from some Ottoman bath buildings in İzmir (Turkey) were investigated in order to understand their relevance as plasters in hot and humid environmental conditions of the baths. For this purpose, ba- sic physical properties, raw material compositions, mineralogical, microstructural and hydraulic properties of brick-lime plasters of bath buildings were determined by XRD, SEM-EDX, AFM and chemical analyses.

\section{Experimental methods}

In the Ottoman period a large number of baths were built during the second half of the 14th and 15th centuries [15]. The primary materials used in these buildings were stone and brick as main construction materials, lime mortar as the joining material and brick-lime plasters as protective layers against water penetration into the structure.

In this study, the characteristics of brick-lime plasters used in the interior spaces of three Ottoman baths (Fig. 1) dated back to the 15th and 16th centuries in Urla and Seferihisar neighborhoods of İzmir (Turkey) were examined [16]. They are Hersekzade Ahmet Paşa Bath, Kamanlı Bath and Düzce Bath which were located very close to each other, constructed nearly in the same period, and they had similar construction techniques.

Furthermore, these buildings are very important because they have survived until today preserving their original materials from deterioration.

Several plaster layers distinguished by their different colors were observed on the upper and lower level wall surfaces of the interior spaces of the baths. Lower level plasters, extended to $1.5 \mathrm{~m}$ height above the existing floor, were mostly composed of two or three rough plaster layers with a dark red colored finishing layer to provide a flat and smooth surface. On the other hand, above the lower level plasters were composed of a rough brick-lime plaster layer with a fine lime plaster layer (Fig. 1).

In this study, 12 relatively sound plaster samples were collected from both lower and upper levels of interior spaces of the baths. Several types of analysis were carried out to identify the basic physical properties, microstructural features and mineralogical and chemical compositions of the plaster samples.

Bulk density and porosity, which are the main physical properties of plasters, were determined by using standard test methods [17]. The amount of lime binder and brick aggregate used in the preparation of the plasters were determined after the dissolution of carbonated lime in dilute hydrochloric acid.

Mineralogical compositions of the plasters which contained both binders and brick aggregates, separated lime binder in the form of white lumps and brick aggregates were identified by using a Philips X-Pert X-ray diffraction spectrometer (XRD). The morphologies, microstructures and chemical compositions of plaster matrices and brick aggregates were determined by using Philips XL-30-SFEG model scanning electron microscope (SEM) coupled with EDS (EDAX Co). Characteristics of brick

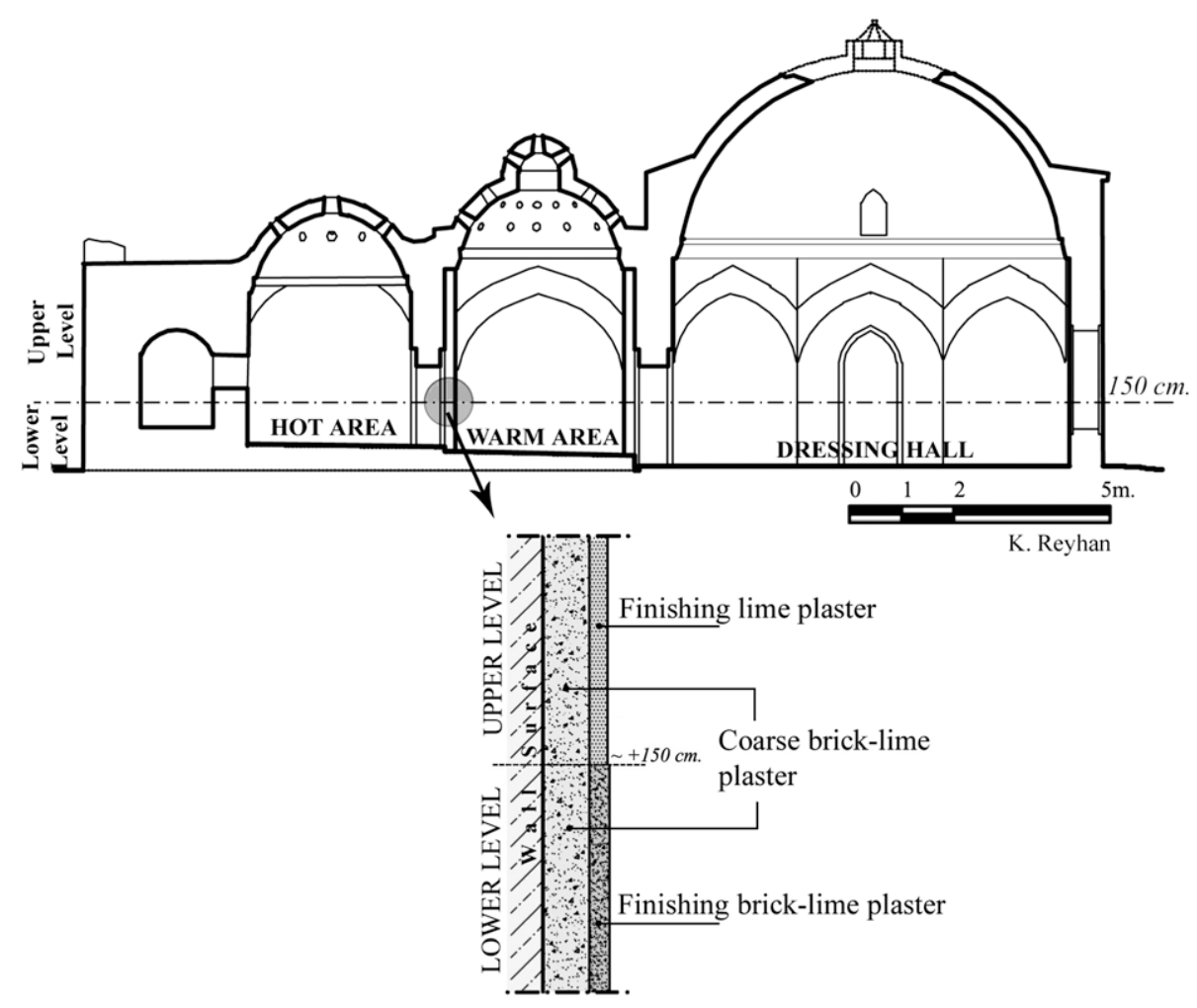

Fig. 1. Section of the Düzce Bath [16] and plaster layers used on the walls. 
aggregate-lime interfaces and their composition were investigated using SEM-EDS and atomic force microscopy (AFM, Digital instruments, MMSPM-Nanoscope 4) on polished sample surfaces.

Hydraulic properties of the mortars and plasters were established by determining the weight loss due to chemically bound water of hydraulic products between 200 and $600{ }^{\circ} \mathrm{C}$, and the weight loss due to the carbon dioxide content of the carbonated lime between 600 and $900{ }^{\circ} \mathrm{C}$ by heating the samples in a laboratory furnace.

The pozzolanic activity of the bricks was found by measuring the differences in electrical conductivities $(\mathrm{mS} / \mathrm{cm})$ before and after the addition of powdered brick (less than $53 \mu \mathrm{m}$ ) into saturated calcium hydroxide solution [18]. The products formed by the reaction between lime and brick powders in a closed plastic bottle stored in the desiccators were determined after 30 days by SEM-EDS and XRD analysis.

\section{Results and discussion}

The physical properties, relative proportions of brick powder and lime, chemical and mineralogical compositions of separated brick powders and microstructural characteristics of plasters are presented and discussed in this section.

\subsection{General characteristics of plasters}

All the examined plasters have a pinkish color, stiff structure and smooth texture. They are well adhered to each other although they are easily distinguishable with border lines. These characteristics may show that brick-lime plasters were prepared by well mixing process of crushed brick aggregates with lime and well applied. There is a lack of information in the Ottoman archives about how such a through mixing had been achieved, how the wall surface was prepared and how plasters were applied on the wall surfaces [6]. The density and the porosity values of all rough plasters were in the range of $1.2-1.7 \mathrm{~g} / \mathrm{cm}^{3}$ and $31-54 \%$ by volume, respectively (Table 1 ). They can be defined as porous and low dense materials compared with the ones manufactured from Portland cement. These values were nearly similar to brick-lime mortars

Table 1

Density, porosity, lime and aggregate ratio (L/A), carbon dioxide and chemically adsorbed water ratio $\left(\mathrm{CO}_{2} / \mathrm{H}_{2} \mathrm{O}\right)$ and mineralogical composition of plasters.

\begin{tabular}{|c|c|c|c|c|c|c|c|}
\hline \multirow[t]{2}{*}{ Sample } & \multirow[t]{2}{*}{$\begin{array}{l}\text { Density }(\mathrm{g} / \\
\left.\mathrm{cm}^{3}\right)\end{array}$} & \multirow[t]{2}{*}{$\begin{array}{l}\text { Porosity } \\
(\%)\end{array}$} & \multirow[t]{2}{*}{$\begin{array}{l}\mathrm{L} / \\
\mathrm{A}\end{array}$} & \multirow[t]{2}{*}{$\begin{array}{l}\mathrm{CO}_{2} / \\
\mathrm{H}_{2} \mathrm{O}\end{array}$} & \multicolumn{3}{|c|}{$\begin{array}{l}\text { Mineralogical } \\
\text { composition }\end{array}$} \\
\hline & & & & & Calcite & Quartz & Albite \\
\hline H.W.L & 1.2 & 46 & $\begin{array}{l}5 / \\
4\end{array}$ & 0.64 & +++ & + & + \\
\hline H.H.L & 1.3 & 46 & $\begin{array}{l}4 / \\
5\end{array}$ & 2.91 & +++ & + & + \\
\hline K.W.L & 1.3 & 47 & $\begin{array}{l}1 / \\
2\end{array}$ & 2.95 & +++ & + & + \\
\hline K.H.L & 1.2 & 54 & $\begin{array}{l}4 / \\
5\end{array}$ & 1.12 & +++ & + & + \\
\hline D.W.L & 1.4 & 43 & $\begin{array}{l}4 / \\
5\end{array}$ & 9.01 & +++ & + & + \\
\hline D.H.L & 1.6 & 36 & $\begin{array}{l}1 / \\
1\end{array}$ & 3.63 & +++ & + & + \\
\hline H.W.U & 1.4 & 43 & $\begin{array}{l}5 / \\
4\end{array}$ & 2.25 & +++ & + & + \\
\hline H.H.U & 1.5 & 41 & $\begin{array}{l}5 / \\
4\end{array}$ & 4.50 & +++ & + & + \\
\hline K.W.U & 1.3 & 47 & $\begin{array}{l}4 / \\
5\end{array}$ & 2.96 & +++ & + & + \\
\hline K.H.U & 1.7 & 33 & $\begin{array}{l}4 / \\
5\end{array}$ & 8.39 & +++ & + & + \\
\hline D.W.U & 1.4 & 48 & $\begin{array}{l}3 / \\
2\end{array}$ & 3.21 & +++ & + & + \\
\hline D.H.U & 1.5 & 41 & $\begin{array}{l}1 / \\
1\end{array}$ & 5.55 & +++ & + & + \\
\hline
\end{tabular}

H: Hersekzade Bath, K: Kamanlı Bath, D: Düzce Bath. W: warm space (Ilkllk), H: hot space (Sicaklk). L: lower level, U: upper level. which had been used in several Byzantine, Roman and Ottoman period buildings [19-21].

Finishing layers that were more vulnerable to chemical and physical action of water were very thin $(1 \mathrm{~mm}$.) to determine their porosity values by standard methods. Hence, SEM has been used to estimate their porosity values by phase analysis of SEM pictures. Analyses results revealed that finishing layers had about 5\% porosity (Fig. 2). Low porosity values show that finishing layers provide water-proof surface that prevent water entry into the bath structure. Porosities of brick aggregates in plasters were also found by SEM analysis due to their small size (Fig. 3). Their porosities were found about $30 \%$. When compared with the porosity and density values of the present-day bricks, they are less dense and high porous materials.

\subsection{The composition of plasters mixtures}

Raw material compositions of lime plasters and mortars can be defined by their lime/aggregate ratios and particle size distributions of aggregates. Lime/aggregate ratios of all plasters were found in the range of $1: 2$ to $3: 2$ by weight (Table 1 ). Any significant difference between lime/aggregate ratios of upper and lower level brick-lime plasters were not observed. Brick aggregates, which had particle sizes greater than $1180 \mu \mathrm{m}$, constituted the major fraction of total aggregates in all plasters.

Lime/aggregate ratio values of various brick-lime mortars used in some historic buildings similarly ranged between these values [9,10,19-22]. This indicated that similar raw material compositions were also used in production of brick-lime plasters, although the use of high amounts of lime was expected in the production of lime plasters.

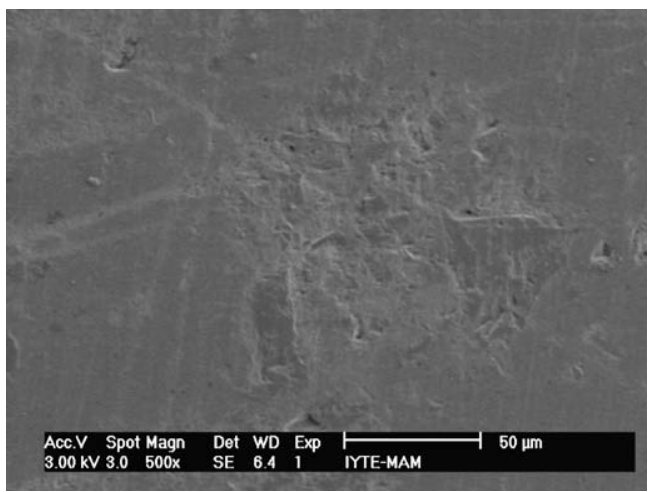

Fig. 2. SE image of finishing plaster layers (K.H.L).

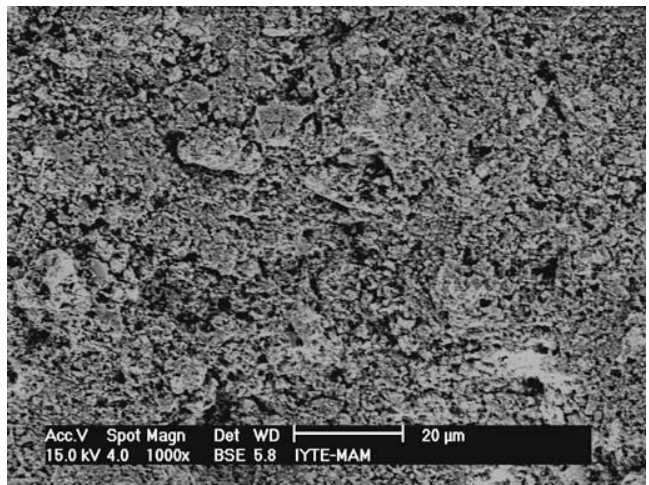

Fig. 3. SE image of brick aggregate (K.H.L). 
3.3. Mineralogical and elemental compositions and microstructural characteristics of binders and brick aggregates

The mineralogical and elemental compositions and microstructural characteristics of "white lumps" representing the binding materials were determined by XRD and SEM-EDS analyses.

In the XRD patterns of white lumps, only sharp calcite peaks were detected (Fig. 4). SEM-EDS analysis indicated that calcite crystals contain high amounts of calcium and low amounts of magnesium (Fig. 5). These analysis results show that high calcium lime was used as binder in the preparation of the plasters.

The mineralogical compositions and firing temperatures of brick aggregates were determined by XRD analysis. XRD patterns of brick aggregates indicated that they were mainly composed of quartz $\left(\mathrm{Q}: \mathrm{SiO}_{2}\right)$, albite $\left(\mathrm{A}:\left(\mathrm{Na}\left(\mathrm{AlSi}_{3} \mathrm{O}_{8}\right)\right)\right.$ and potassium feldspar (F: $\mathrm{KAl}_{2} \mathrm{Si}_{2} \mathrm{O}_{5}(\mathrm{OH})_{4}$ ) (Fig. 6). Additionally, a diffuse band between 20 and 30 degrees $2 \theta$ in the XRD pattern was observed. This band shows the presence of amorphous substances originated from the high amounts of heated clay minerals [23]. This observation suggested that the brick aggregates were manufactured by using soil materials of high clay content.

XRD analyses were also used to predict the firing temperatures of the brick aggregates. If the bricks are manufactured by using Ca- rich clays, the presence of gehlenite $\left(800^{\circ} \mathrm{C}\right)$, diopside $\left(850{ }^{\circ} \mathrm{C}\right)$ and wollastonite $\left(900-1050^{\circ} \mathrm{C}\right)$ minerals indicate high firing temperature of bricks [24]. If Ca-poor clays used, the presence of hematite indicates that firing temperature of bricks was about $850{ }^{\circ} \mathrm{C}$ [24]. In the XRD patterns of brick aggregates, minerals that were formed at high temperatures were not observed. This revealed that they were heated at temperatures up to $850^{\circ} \mathrm{C}$.

This finding was also supported by microstructural analysis of brick aggregates. Microstructure of brick aggregates indicated the presence of dispersed filler grains of feldspar, quartz and amorphous substances. Amorphous substances, which consisted of mainly silicon and aluminum, may show the presence of metakaolin derived from the heating of kaolinite at temperatures lower than $900^{\circ} \mathrm{C}$ (Fig. 7).

The elemental composition analysis of aggregates indicated that all the bricks mainly consisted of $\mathrm{SiO}_{2}, \mathrm{Al}_{2} \mathrm{O}_{3}$ and moderate amounts of $\mathrm{Fe}_{2} \mathrm{O}_{3}, \mathrm{MgO}, \mathrm{Na}_{2} \mathrm{O}, \mathrm{K}_{2} \mathrm{O}, \mathrm{CaO}$ (Table 2). However, the amounts of $\mathrm{Fe}_{2} \mathrm{O}_{3}$ in aggregates of finishing layers were found to be higher than those of rough ones. This may be explained by conscious addition of hematite powder to the finishing layers in order to obtain water-proof and red color surfaces.

XRD patterns of the plaster matrices including lime binder and brick aggregates showed that they were mainly composed of cal-

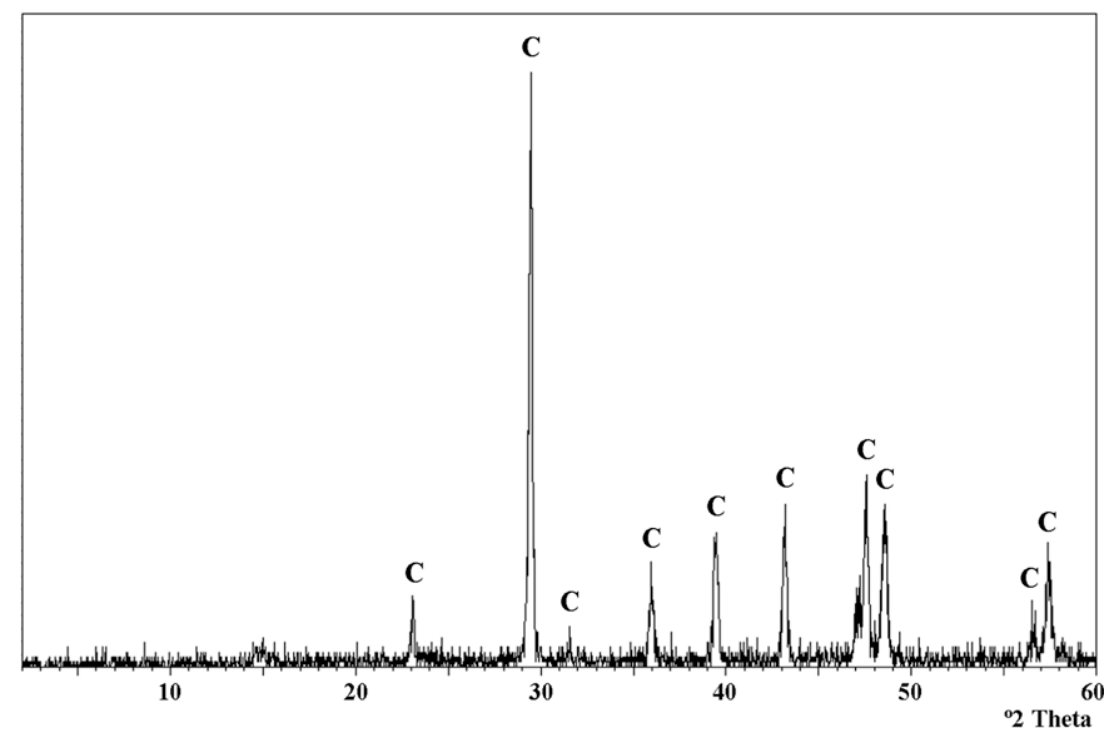

Fig. 4. A typical XRD pattern of a white lump in plasters (C: calcite) (D.W.L).

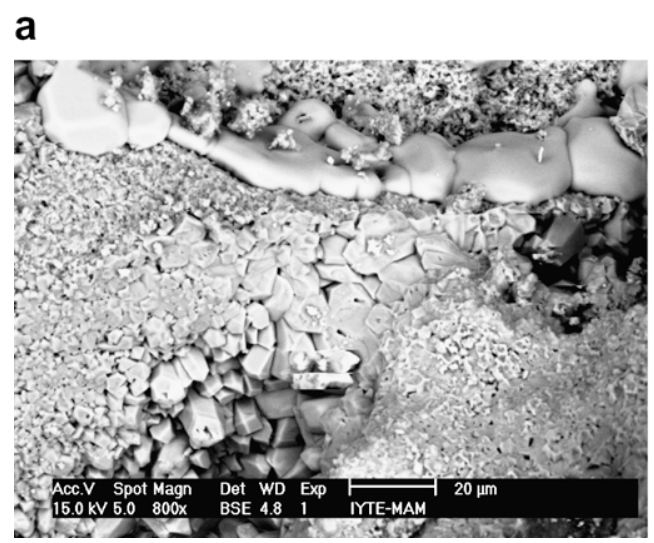

b

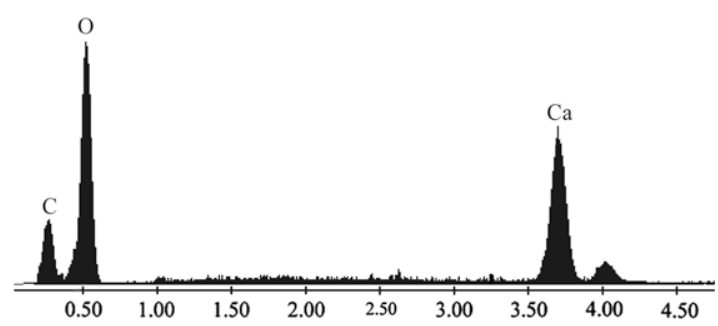

Fig. 5. BSE image (a) and EDS spectrum (b) of white lump in plaster (K.H.L). 


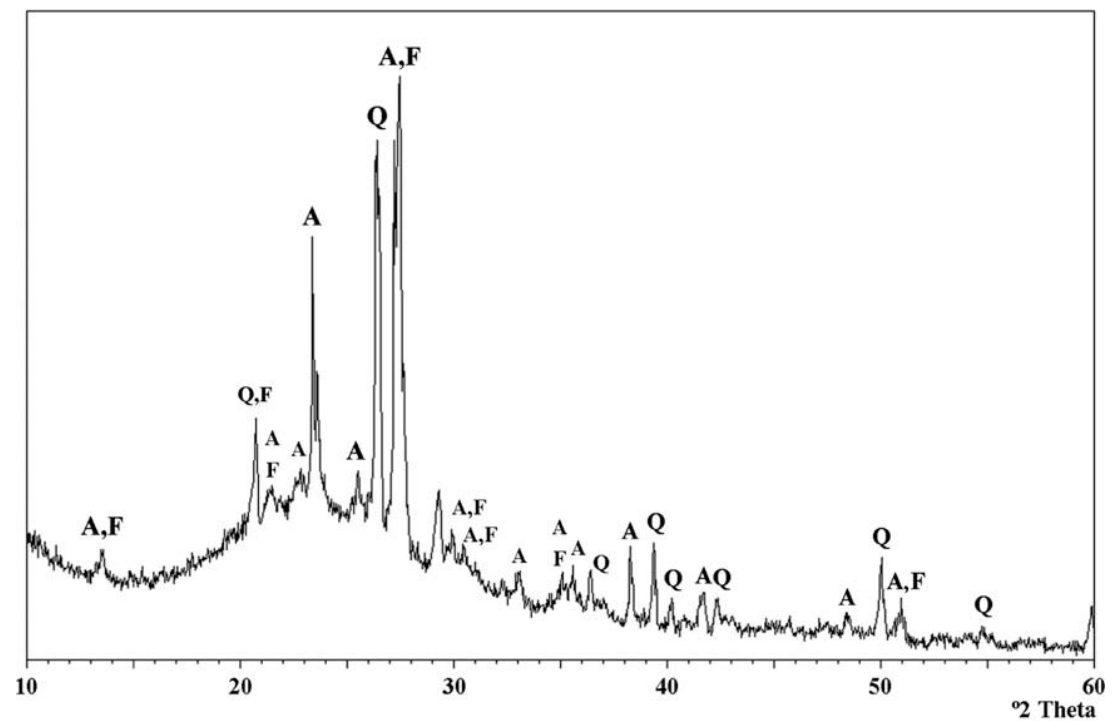

Fig. 6. A typical XRD pattern of brick aggregates in plasters (H.W.U) (A: albite, Q: quartz, F: feldspar).

a

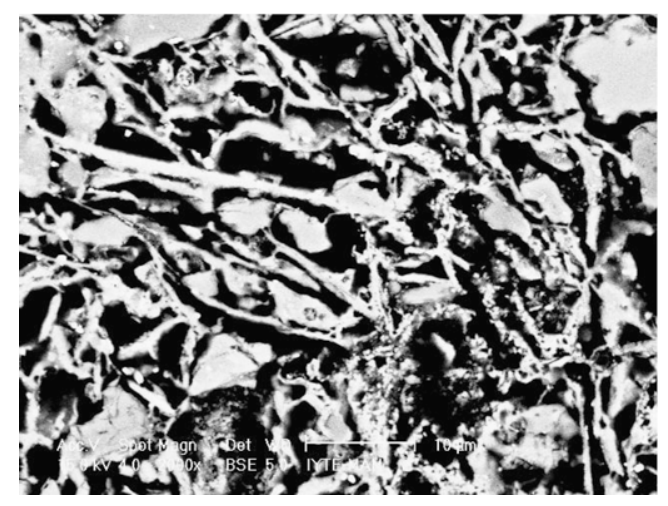

b

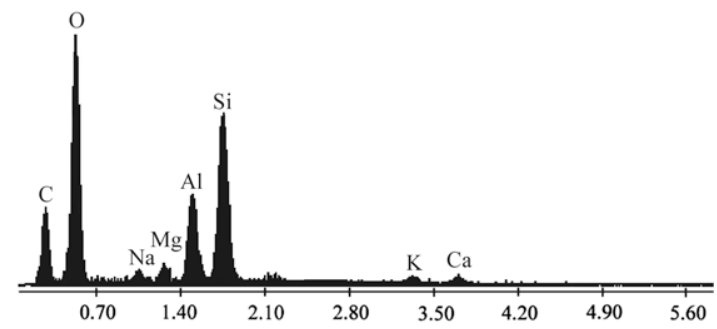

Fig. 7. BSE image (a) and EDS spectrum (b) of amorphous substances in brick aggregates (K.H.L).

Table 2

Pozzolanic activities (PA), mineralogical and chemical compositions of brick aggregates.

\begin{tabular}{|c|c|c|c|c|c|c|c|c|c|c|c|}
\hline \multirow[t]{2}{*}{ Sample } & \multirow[t]{2}{*}{ Pozzolanic activity $(\mathrm{mS} / \mathrm{cm})$} & \multicolumn{4}{|c|}{ Mineralogical composition } & \multicolumn{6}{|c|}{ Chemical composition (\%) } \\
\hline & & Q & A & $\mathrm{F}$ & $\mathrm{AP}$ & $\mathrm{SiO}_{2}$ & $\mathrm{Al}_{2} \mathrm{O}_{3}$ & $\mathrm{Fe}_{2} \mathrm{O}_{3}$ & $\mathrm{MgO}$ & $\mathrm{K}_{2} \mathrm{O}$ & Other \\
\hline H.W.L & 6.7 & +++ & ++ & + & ++ & $92.6 \pm 0.8$ & $4.2 \pm 0.5$ & - & - & $0.8 \pm 0.0$ & $2.4 \pm 0.4$ \\
\hline H.H.L & 5.9 & ++ & +++ & + & + & $81.3 \pm 1.2$ & $8.8 \pm 0.3$ & $3.4 \pm 0.4$ & $0.9 \pm 0.2$ & $2.1 \pm 0.2$ & $3.4 \pm 0.5$ \\
\hline K.W.L & 6.5 & ++ & +++ & + & + & $77.3 \pm 0.6$ & $10.0 \pm 0.1$ & $5.3 \pm 0.5$ & $1.7 \pm 0.3$ & $1.9 \pm 0.1$ & $3.7 \pm 0.5$ \\
\hline K.H.L & 5.8 & +++ & ++ & + & + & $83.4 \pm 1.4$ & $6.8 \pm 0.4$ & $4.0 \pm 0.8$ & $1.7 \pm 0.3$ & $1.0 \pm 0.1$ & $3.1 \pm 0.2$ \\
\hline D.W.L & 6.3 & +++ & +++ & + & + & $80.9 \pm 0.4$ & $7.9 \pm 0.3$ & $4.7 \pm 0.5$ & $1.5 \pm 0.2$ & $1.6 \pm 0.2$ & $3.4 \pm 0.2$ \\
\hline D.H.L & 3.1 & ++ & +++ & + & + & $73.2 \pm 0.8$ & $12.2 \pm 0.2$ & $4.7 \pm 2.1$ & $1.9 \pm 0.1$ & $2.5 \pm 0.0$ & $5.4 \pm 0.3$ \\
\hline H.W.U & 7.3 & ++ & +++ & + & + & $87.6 \pm 0.8$ & $5.8 \pm 0.3$ & $2.3 \pm 0.2$ & $0.6 \pm 0.6$ & $1.0 \pm 0.1$ & $2.7 \pm 0.4$ \\
\hline H.H.U & 3.9 & +++ & +++ & + & + & $76.3 \pm 0.9$ & $12.4 \pm 0.1$ & $5.6 \pm 1.3$ & - & $3.1 \pm 0.4$ & $2.6 \pm 0.2$ \\
\hline K.W.U & 4.8 & ++ & +++ & + & + & $84.8 \pm 1.1$ & $8.8 \pm 0.2$ & $2.6 \pm 0.8$ & - & $1.5 \pm 0.5$ & $2.3 \pm 0.3$ \\
\hline K.H.U & 1.6 & +++ & +++ & + & + & $68.5 \pm 0.7$ & $14.2 \pm 0.1$ & $7.2 \pm 0.2$ & $1.8 \pm 0.2$ & $3.1 \pm 0.1$ & $5.2 \pm 0.4$ \\
\hline D.W.U & 6.8 & +++ & +++ & + & ++ & $82.1 \pm 0.8$ & $7.1 \pm 0.4$ & $5.2 \pm 0.2$ & $1.4 \pm 0.3$ & $1.3 \pm 0.1$ & $2.9 \pm 0.3$ \\
\hline D.H.U & 3.3 & +++ & + & + & + & $59.0 \pm 3.3$ & $22.7 \pm 2.7$ & $8.3 \pm 0.5$ & $2.9 \pm 0.1$ & $4.2 \pm 0.3$ & $2.9 \pm 0.6$ \\
\hline
\end{tabular}

Q: quartz, A: albite, F: feldspar potassian, AP.: amorphous phase. Other: $\mathrm{CaO}, \mathrm{Na}_{2} \mathrm{O}$.

cite (C: $\left.\mathrm{CaCO}_{3}\right)$, quartz (Q: $\left.\mathrm{SiO}_{2}\right)$ and albite $\left(\mathrm{A}:\left(\mathrm{Na}\left(\mathrm{AlSi}_{3} \mathrm{O}_{8}\right)\right)\right.$ (Fig. 8). Calcite was derived from carbonated lime, while quartz and albite were derived from brick powders. The expected main XRD peaks of calcium silicate hydrate and calcium aluminate hydrate formations were not observed in the plaster matrices. This might be due to amorphous characters of these hydraulic products [25]. 


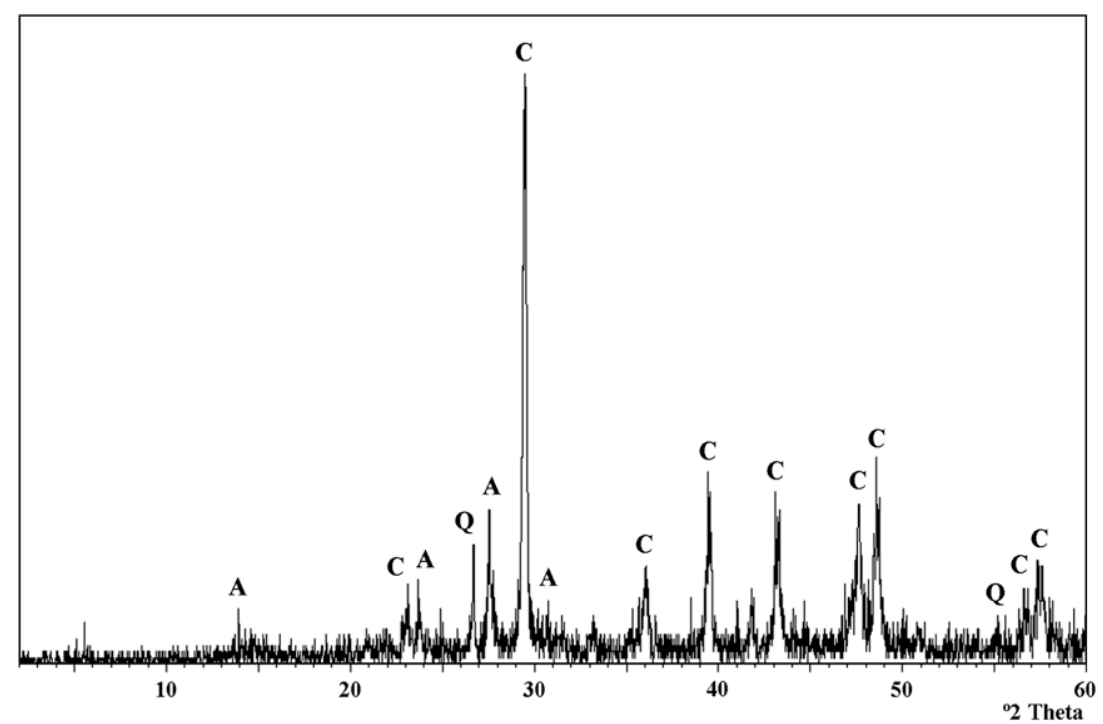

Fig. 8. A typical XRD pattern of plaster matrix (C: calcite, A: albite, Q: quartz) (K.H.L).

\subsection{Pozzolanicity of brick aggregates}

Pozzolanicity of the brick aggregates was determined by following the reaction between lime and powdered brick by electrical conductivity measurements. Pozzolanic activity values of brick aggregates were found to be mostly more than $2 \mathrm{mS} / \mathrm{cm}$ which can be accepted as good pozzolan [18].

The products formed by the reaction between lime and brick after 30 days were determined by SEM-EDS and XRD analysis. Before, reaction of brick powders with lime, amorphous structures a

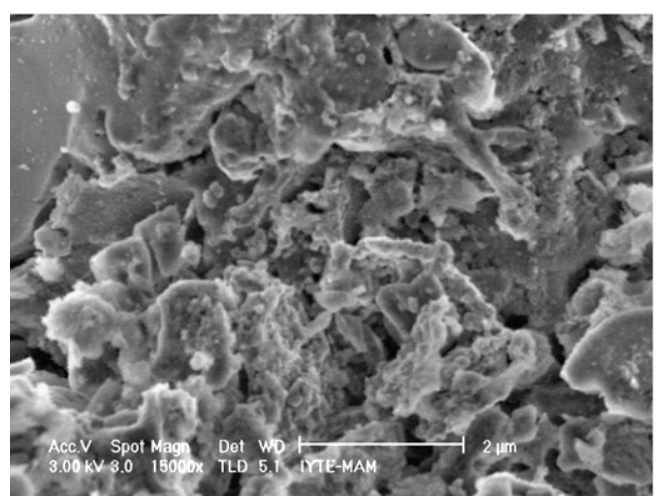

b

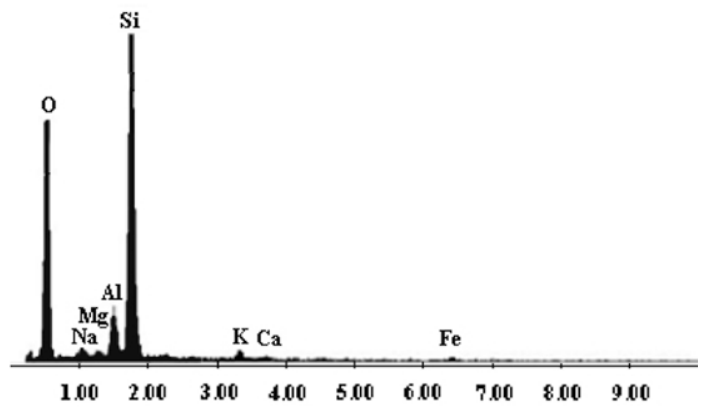

Fig. 9. SE image (a) and EDS spectrum (b) of brick aggregate before reacted with lime (H.S.L).

a

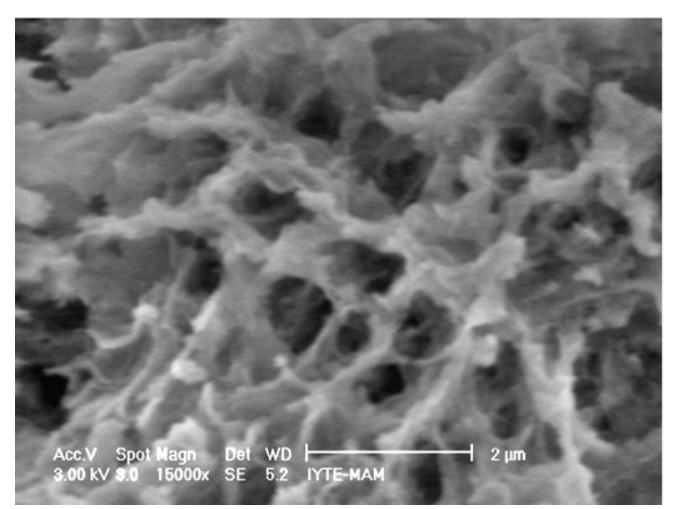

b

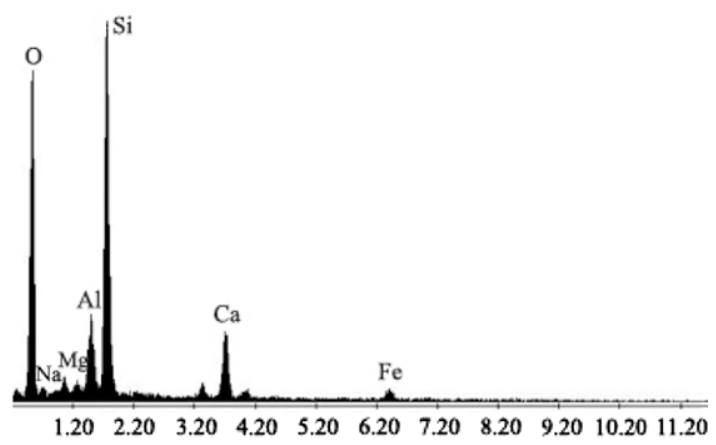

Fig. 10. SE image (a) and EDS spectrum (b) of brick aggregate after reacted with lime (H.S.L). 
that composed mainly silica were observed in SEM-EDS analysis (Fig. 9). After 30 days, gel like structures that mainly composed of calcium and silicon were observed in SEM images (Fig. 10). This might indicate the formation of calcium silicate hydrate (CSH). However, the expected main peaks of calcium silicate hydrate and calcium aluminate hydrate formations were not observed in XRD spectrum. This could be explained by the amorphous character of the formed CSH [25].

\subsection{Hydraulic properties of plasters}

Hydraulic properties of the plasters were established by determining the weight loss of the powdered plaster samples between $200-600{ }^{\circ} \mathrm{C}$ and $600-900{ }^{\circ} \mathrm{C}$. Weight losses between $200-600{ }^{\circ} \mathrm{C}$ and $600-900{ }^{\circ} \mathrm{C}$ were mainly due to the loss of chemically bound water, and the carbon dioxide, respectively. If the ratio of $\mathrm{CO}_{2} /$ chemically bound water $\left(\mathrm{H}_{2} \mathrm{O}\right)$ is between 1 and 10 , the plasters can be accepted as hydraulic [10,19].

Brick-lime plaster samples had $\mathrm{CO}_{2}$ and chemically bound water percents ranging between $10-29 \%$ and $3-15 \%$, respectively. The ratios of $\mathrm{CO}_{2} / \mathrm{H}_{2} \mathrm{O}$ were lower than 10 , ranging between 0.64 and 9.01 (Table 1). Hence, all the brick-lime plaster samples could be regarded as hydraulic. Hydraulic character of brick-lime plasters could be attributed to the use of pozzolanic crushed brick aggregates.

\subsection{Durability of plasters in hot and humid environments of the baths}

On-site observations of the plasters indicated that they remained in perfectly good condition without loss of strength and adhesion to the wall. Their durability can be explained by their microstructural features, hydraulic characters, use of porous and pozzolanic brick aggregates and precipitation of small and dense structure of calcite crystals at plaster surface and inside the pores of brick aggregates by dissolution and precipitation reaction of carbonated lime in humid and hot environmental conditions of the baths.

Microstructural features of the plaster matrices were identified by scanning electron microscope coupled with EDS and AFM. Strong adhesion was indicated between aggregates and lime matrix due to the deep penetration of lime into bricks in SEM and AFM analysis. Brick-lime interfaces are generally free from micro cracks and pores (Fig. 11). Interfaces were composed largely of calcium, silicon and aluminum (Fig. 11). AFM image shows a uniform topography and the homogeneous surfaces without any discontinuity between lime and brick aggregates in the plaster matrices (Fig. 12). The width of the brick-lime interfaces found by AFM was in the range of $2-10 \mu \mathrm{m}\left(10^{-3} \mathrm{~mm}\right)$ (Fig. 12). This may indicate the formation of hydraulic compounds, such as calcium silicate hydrates and calcium aluminate hydrates at the interface. They are produced by the reaction between amorphous substances derived by heated clay minerals in brick aggregates with lime (Eqs. (1) and a

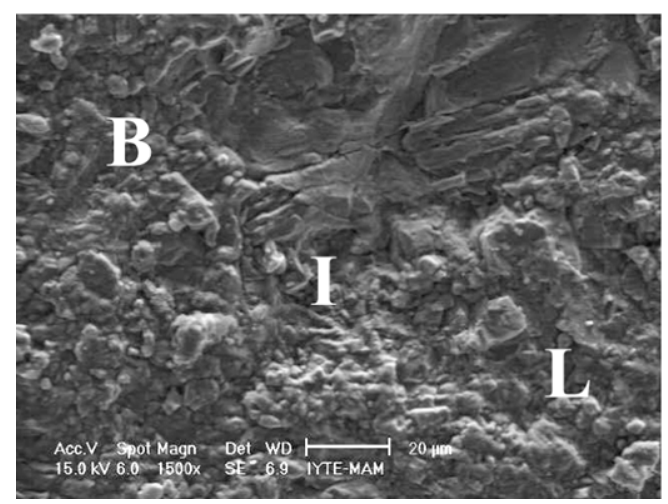

b

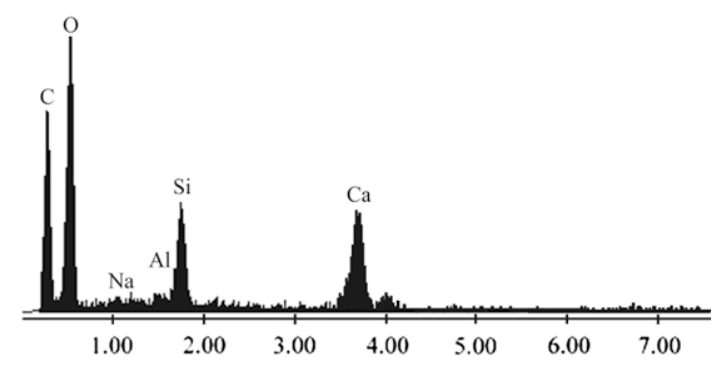

Fig. 11. SE image (a) and EDS spectrum (b) of the interface (I) between lime (L) and the brick aggregate (B) (H.S.L).

a

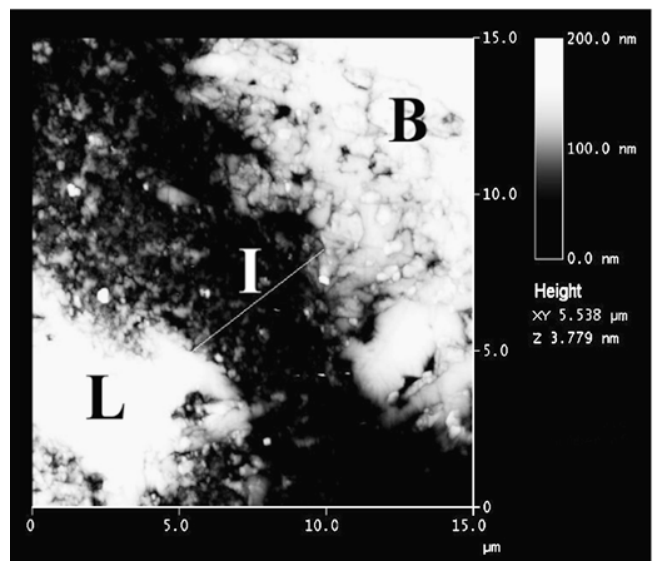

b

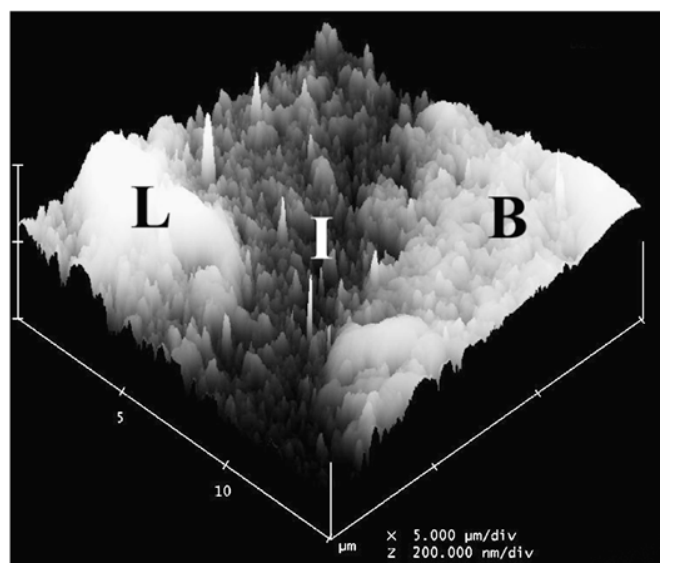

Fig. 12. AFM image showing the thin brick-lime interface (a) and topography (b) of the interface (I) between the mortar matrix (L) and the brick aggregate (B) (K.H.L). 
a

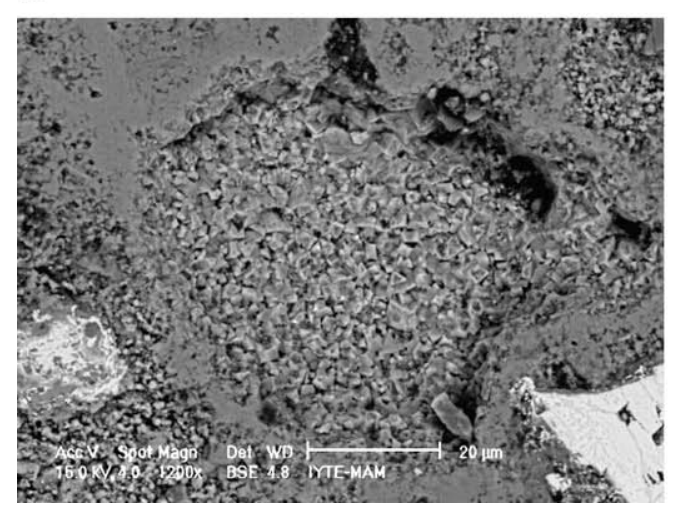

b

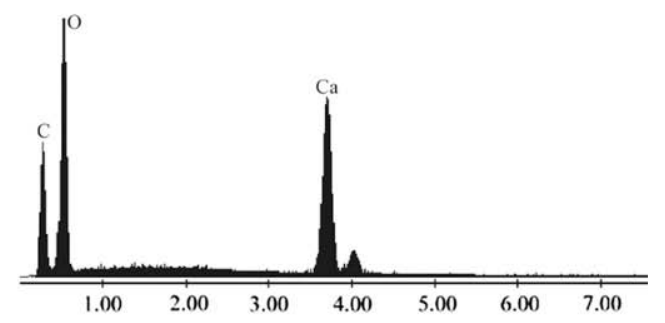

Fig. 13. SE image (a) and EDS spectrum (b) of micritic calcite crystals precipitated in the pores of the brick aggregates (D.H.U).

(2)) [26]. This reaction is more favorable under relatively high humidity and high temperature. Hence, the formation of calcium silicate hydrate $(\mathrm{CSH})$ and calcium aluminate hydrate $(\mathrm{CAH})$ are favorable in the climatic conditions of bath buildings. The presence of large amount of water in the chemical compositions of calcium silicate hydrate and calcium aluminate hydrate makes the plaster more durable to the humid atmosphere of the baths

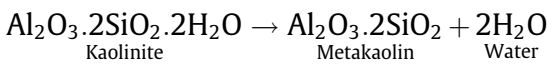

$$
\begin{aligned}
& \underset{\text { Metakaolin }}{\mathrm{Al}_{2} \mathrm{O}_{3} .2 \mathrm{SiO}_{2}}+\underset{\text { Lime }}{7 \mathrm{Ca}(\mathrm{OH})_{2}}+19 \mathrm{H}_{2} \mathrm{O} \\
& \rightarrow 4 \mathrm{CaO} . \mathrm{Al}_{2} \mathrm{O}_{3} \cdot 19 \mathrm{H}_{2} \mathrm{O}+3 \mathrm{CaO} \cdot 2 \mathrm{SiO}_{2} \cdot 7 \mathrm{H}_{2} \mathrm{O}
\end{aligned}
$$

Due to the humid and hot conditions of the baths, all plaster surfaces and the pores of the brick aggregates are covered with calcite depositions by the subsequent dissolution of carbonated lime. Deposit layers were composed of small sized calcite crystals containing high amounts of calcium oxide over 95\% (Fig. 13). Despite dissolution of carbonated lime binder and its subsequent precipitation, the brick-lime plasters of the baths stood in perfectly good condition. This may be explained by the small grain size of the chemically deposited calcite in water and the subsequent build up of a very dense structure.

On the other hand, lime plasters used on the upper level of the bath spaces as finishing layers lost their strength, hardness and hydro-thermal stability. Due to the subsequent dissolution and precipitation reaction, several deposited calcite layers were formed. Layers were very porous and easily crumbled (Fig. 14). Although lime plasters were not durable in the hot and humid environmen-

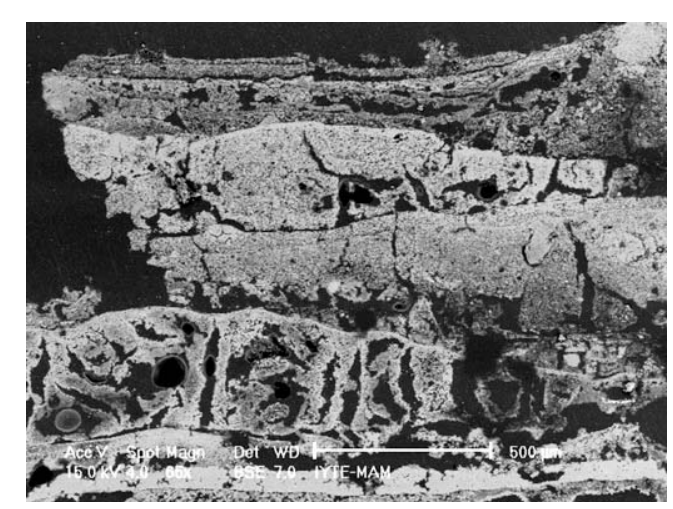

Fig. 14. SE picture of deteriorated lime plaster used on the upper parts of the bath spaces (H.H.U). tal conditions of the baths, it is difficult to explain the reasons for their usage. All these observations may show that brick-lime plasters are suitable water-proof materials for the climatic conditions of bath buildings.

\section{Conclusions}

All brick-lime plasters used in different spaces and levels of baths have almost the same physical properties, chemical and mineralogical compositions, microstructural and hydraulic properties. Brick-lime plasters are porous and low dense materials. They are composed of lime and brick aggregates. Their lime/aggregate ratios are varied in the range of $1: 2$ and 3:2 by weight. Aggregates with particle sizes greater than $1180 \mu \mathrm{m}$ constitute the major fraction of the total aggregates.

They are durable and stable materials in moist, humid and hot conditions of the bath buildings. Their durability can be explained by the formation of calcium silicate hydrate and calcium aluminate hydrate that are formed at the surfaces and in the pores of the brick aggregates by the reaction of lime with brick aggregates. These products provide strong adhesion bonds between lime and aggregates, which make the plasters durable and stiff in humid and hot environmental conditions of the baths.

The bricks used as aggregates in the plasters have good pozzolanicity due to high amounts of amorphous substance derived by using clay-rich soil in their manufacturing. Brick aggregates were little vitrified and did not contain high temperature products like mullite, suggesting low firing temperatures.

As a result of this study, durable brick-lime plasters in moist, humid and hot conditions of the bath buildings were consciously prepared and applied to protect the main structure of the historic bath buildings from water penetration.

\section{Acknowledgments}

The authors thank the researchers of the Centre for Materials Research at the İzmir Institute of Technology for XRD, SEM-EDS and AFM analyses during the experimental stage of this study.

\section{References}

[1] Bugini R, Salvatori A, Capannesi G, Sedda AF, D’Agostini C, Giuliani CF. Investigation of the characteristics and properties of 'cocciopesto' from the ancient Roman period. In: Thiel MJ, editor. Proceedings of the international UNESCO-RILEM congress, June 1993, Paris, France. p.386-93.

[2] Lea FM. Investigations on pozzolanas. Build Res, Tech Paper 1940;27:1-63.

[3] Vitruvius. The ten books on architecture. In: Morgan $\mathrm{MH}$, editor. Dover Publications Inc.; 1960.

[4] Pasley CW. Observation on limes. Dorset: Donhead Publishing; 1997. 
[5] Vicat LJ. Mortars and cements. Davey: Donhead Publishing; 2003 [First published in 1837 by John Weale, High Holborn, London].

[6] Akman MS, Güner A, Aksoy IH. The history and properties of khorasan mortar and concrete. In: Proceedings II international congress on the history of Turkish and Islamic science and technology in the 16th century, April 28-May 2 1986, İstanbul, Turkey. p. 101-12.

[7] Moropoulou A, Bakolas A, Bisbikou B. Characterization of ancient, Byzantine and later historic mortars by thermal and X-ray diffraction techniques. Thermochim Acta 1995;269/270:779-95.

[8] Moropoulou A, Cakmak AS, Biscontin G, Bakolas A, Zendri E. Advanced Byzantine cement based composites resisting earthquake stresses: the crushed brick/lime mortars of Justinian's Hagia Sophia. Constr Build Mater 2002;16:543-52.

[9] Moropoulou A, Bakolas A, Bisbikou K. Physico-chemical adhesion and cohesion bonds in joint mortars imparting durability to the historic structures. Constr Build Mater 2000;14:35-46.

[10] Bakolas A, Biscontin G, Moropoulou A, Zendri E. Characterization of structural Byzantine mortars by thermogravimetric analysis. Thermochim Acta 1998;321(1-2):151-60.

[11] Biscontin G, Birelli MP, Zendri E. Characterization of binders employed in the manufacture of Venetian historic mortars. J Cult Herit 2002;3(1):31-7.

[12] Baronio G, Binda L, Lombardini N. The role of brick pebbles and dust in conglomerates based on hydrated lime and crushed bricks. Constr Build Mater 1997;11(1):33-40.

[13] Baronio G, Binda L. Study of the pozzolanicity of some bricks and clays. Constr Build Mater 1997;11(1):41-6.

[14] Böke H, Akkurt S, İpekoğlu B, Uğurlu E. Characteristics of brick used as aggregate in historic brick-lime mortars and plasters. Cem Concr Res 2006;36(6):1115-22.

[15] Büyükdigan I. A critical look at the new functions of Ottoman baths. Build Environ 2003;38:617-33.
[16] Reyhan K. Construction techniques and materials of Ottoman period baths in Urla-Seferihisar region. MSc thesis, Graduate School of Engineering and Sciences, İzmir Institute of Technology, 2004.

[17] RILEM Commission 25 PEM. Tests defining the structure. Mater Constr 1980;13(75):177-81.

[18] Luxán MP, Madruga F, Saavedra J. Rapid evaluation of pozzolanic activity of natural products of conductivity measurement. Cement Concr Res 1989;19:63-8

[19] Moropoulou A, Bakolas A, Bisbikou K. Investigation of the technology of historic mortars. J Cult Herit 2000;1:45-8.

[20] Moropoulou A, Çakmak AS, Lohvyn N. Earthquake resistant construction techniques and materials on Byzantine monuments in Kiev. J Soil Dyn Earthq Eng 2000;19:603-15.

[21] Güleç A, Tulun T. Studies of old mortars and plasters from the Roman Byzantine and Ottoman period of Anatolia. Arch Sci Rev 1996;39:3-13.

[22] Moropoulou A, Cakmak A, Polikreti K. Provenance and technology investigation of Hagia Sophia bricks, İstanbul, Turkey. J Am Ceram Soc 2002;85(2):366-72.

[23] Sujeong L, Kim YJ, Moon HS. Phase transformation sequence from kaolinite to mullite investigated by an energy-filtering transmission electron. J Am Ceram Soc 1999;10:2841-8.

[24] Cardiano P, Ioppola S, De Stefano C, Pettignano A, Sergi S, Piraino P. Study and characterization of the ancient bricks of monastery of San Filippo di Fragalá in Frazzanò (Sicily). Anal Chim Acta 2004;519:103-11.

[25] Haga K, Shibata M, Hironaga M, Tanaka S, Nagasaki S. Silicate anion structural change in calcium silicate hydrate gel on dissolution of hydrated cement. J Nucl Sci Technol 2002;39(5):540-7.

[26] Prince W, Castanier G, Giafferi JL. Similarity between alkali-aggregate reaction and the natural alteration of rocks. Cement Concr Res 2001;31:271-6. 